\title{
POTENTIALITIES OF INTENSIVE GRASSLAND FARMING
}

By P. D. SEARS, Grasslands Division, Department of Scientific and Industrial Research, Palmerston North.

It is becoming increasingly obvious to all that the economic and national destiny of New Zealand must lie in a whole-hearted development of our agriculture, and a major intensification of our grassland practice in all its branches.

For this belief New' Zealand has a very strong balance of relative national advantages over limitations. On the assets side we have (a) our extremely favourable climate for pasture production and animal husbandry; (b) our established range of pedigreed and certified pasture plants ; (c) a good share of easy topography and few problem soils ; (d) our long term marketing contract; and, finally, but most important, (e) the very high mental standard of our farmers.

Thus on the limitations side there is little real difficulty except our distance from markets and also the general national unawareness of our national possibilities as an intensive grassland farming country. In my view the only way to overcome this latter is by a considerable extension of all our advisory services, especially if these were more closely knit with our producer organisations, e.g., dairy factories might well serve as the headquarters for local farm advice and service to their particular group.

In this short paper it is impossible to cover in detail our full pasture improvement policy. All I propose is to outline briefly four of the main aspects of our background work which has led to one of the major farm systems which we consider as sound, more especially for dairy production. These aspects are (a) pedigree strains, (b) soil fertility, (c) grazing practice, (d) special animal requirements. At the outset I emphasise that all these aspects are interdependent and "equally important; also that we must at all times be prepared to modify our outlooks and practices to fit 
in with changes in plant populations, fertiliser supplies, and general production and marketing policies. .

\section{Pedigree Strains}

To previous conferences of this association $\mathrm{Mr}$ Corkill (1) has given details of the breeding and characteristics of the Grasslands Division pedigree strains. In broad outline. the list is as follows. In the grasses we have perennial, Italian, and short-rotation ryegrass, cocksfoot, and timothy. Of the clovers there are white, Montgomery, and broad red, while a good start has been made on the Lotus group. As an indication of the value of these pedigree strains can be quoted the greater palatability, the lower rust incidence, the greater persistency, and a considerable increase in annual production of the pedigree perennial rvegrass over the best "natural old pasture" strains. With Italian ryegrass the improvement has been relatively even greater, with an extra production potential of over 16 per cent in the first year and over 180 per cent in the second year. The short-rotation ryegrass is a new strain which was bred primarily to replace the old South Island non-perennial strains, and which is performing this task most satisfactorily. In addition it is proving of outstanding value for North Island intensive sheep and dairy farming because of its characters of greater winter growth and better palatability than the true perennial, together with good persistence under appropriate soil fertility and grazing conditions. Continual improvements are being made by Mr Corkill with this strain, trial results at Palmerston North, Lincoln, and Gore substations all showing a 50 per cent. increase in persistency of the latest models compared with the earliest releases, without any loss of vigour or palatability.

Parallel advances have been made with the clovers, pedigree white having about 15 per cent. greater annual production and a better seasonal spread than the best "natural" strains, and over 100 per cent. greater than the average volunteer types, which are very shortlived and little better than annuals. Similarly in the red clovers the new pedigree strains have advantages of over 10 per cent. above the best "natural" strains available.

\section{Soil Fertility}

We must at all times remember that these good strains are gross feeders and that it is quite hopeless 
expecting good production unless efforts are constantly made to keep up the plant food supply. The major nutrients used each year by an acre of high-production pasture are the equivalent of those in over 1 ton of sulphate of ammonia, nearly 1 ton of 30 per cent. K salts, $8 \mathrm{cwt}$. of superphosphate, and $4 \mathrm{cwt}$. of lime. Fortunately, however, we do not have to provide these large amounts each year out of. the bag or from our soil reserves. Under our permanent grazing system most of these nutrients are returned direct through the animal after it has taken the energy of the food and the small amounts of nitrogen and minerals retained for its growth and production. At Grasslands we have measured that most of the returned nitrogen and potash is in the urine, while the dung contains the bulk of the phosphate and lime, as well as the other undigested residues (2).

It is thus easy to appreciate how essential it is to keep this cycle of plant growth and animal return of the dung and urine in balance, and constantly operating to get the maximum turnover of plant nutrients and associated leaf growth. We can thus also easily appreciate our national advantage over countries where climate forces them to indoor feeding, with the conservation taking out of the cycle large quantities of plant nutrients for a considerable part of each year, as well as the other nutrient losses involved. Even greater of course, are our advantages in producing butterfat, meat, and wool, none of which products drains the soil fertility anywhere near as much as total grain or forage crops.

However, it is, of course, little use having such advantages unless we use them. For instance every effort should be made toward controlled grazings to ensure an even return of stock droppings within paddocks, the avoidance of "day" and "night" paddocks, the feeding back of hay, silage, and crops on to the soil where these were grown, the collection of shed droppings (both pig and cow), and their return to the paddocks ; all of these will help in stopping nutrient losses within and off the farm. We must at all times remember that leaching and other localised losses increase with concentrations in the soil or on its surface, and that it is much better to return the nutrients thinly and often, rather than in large concentrations at various points on the farm.

Careful thought should always also be given to 
fertiliser applications and use of these to balance up unavoidable transfers within the- farm, as well as for replacement of losses from the' farm. Special attention, for instance, is necessary to correct for fertility transfers on hill country by the animals to their tracks and camping areas. Differential fertiliser usage is necessary also in paddocks bordering roadways, etc., with associated stock-carried soil fertility movements from those boundaries, and also to $0^{3}$ compensate for other stock movements to trees, troughs, gateways, etc. Parallel with these attacks on the fertility maintenance problem must be efforts to increase fertility not only for greater growth; but also to compensate for unavoidable losses through leaching and other processes.

Essentially this building process is one of providing the extra soil minerals needed and getting the appropriate combinations of legume, grass, and soil populations for maximum build-up of nitrogen, organic matter, and soil structure for each local set of conditions.

Details ' of some of our trials at Grasslands on this fertility building cycle have been published previously (3 and 4) but the main points demonstrated are (a) the essential nature of the clovers in the sward and the great superiority of the pedigree N.Z. white clover as a nitrogen building agent (b) the very rapid deterioration of cloverless swards, and the lack of response to added phosphates and lime without clovers (c) a direct relationship between pasture yields and yields of subsequent forage crops, as well as the development parallel to pasture production, of earthworms, grass grubs, and soil structure.

The practical application of these results is very obvious. The first is the basic necessity for clovers, the choice of the most suitable species, and the use of the best strains. Added to this is the whole question of their incorporation by oversowing taking into account times of sowing and grazing and fertiliser conditions. Then there are the questions of sowing in mixtures, the complication of season, fertiliser, moisture and light and grazing effects on the young clover seedlings. Secondly is the constant examination of our fertiliser responses to. determine how much we are losing for want of clovers, and also whether or not we will need more fertilisers or perhaps some of a different nature, if we are able to get full results from added clovers. Thirdly there is the whole ques- 
tion of cropping, to cash in on built-up soil fertility, and for special needs. One rather obvious fact is that we should take care to work soil fertility up to, a cropping standard rather than to take a crop only when the pasture is run out. In the latter case crops will be poor; a better approach would be to sow direct back to good pasture species so that fertility levels can be. increased rapidly. But by far the most important point illustrated is the really ephemeral nature of soil fertility particularly insofar as the nitrogen and organic matter fractions are concerned, and we must always work from the point of view that without constant care, our soil fertility will rapidly slip through our Angers.

\section{Grazing Management}

Parallel with the need to adjust grazings for the correct soil-nutrient balance is the essential factor of grazing control to get the light conditions and leaf growth at the optimum for the desired species, whilst at the same time endeavouring to control the undesirable species and prevent weed establishment.

For instance, continued close grazing favours perennial ryegrass, browntop, danthonia, and white clover, relatively to Italian and short-rotation ryegrass, prairie grass; cocksfoot, fog, and red clover, because of the differences in habit and number of the regenerative tillers of these species. Other marked sward changes can moreover be produced by seasonal variations in species growth. Thus heavy winter grazing followed by summer spells will depress fog relatively to cocksfoot and vice versa ; heavy early spring grazing followed by late spring and early summer spells will depress ryegrass and encourage white clover and/or browntop.

Also to be considered are the relative rates of establishment and early growth of the many species, clovers being in this respect at a disadvantage to the grasses, while the relative unpalatability of many weed, species also causes difficulties.

The total farm grazing plan must therefore be such as to allow the desired species to grow at the times when they will grow, and to hard graze the pasture at those times undesired species are making their major seasonal run of growth. At the same time allowance must be made to protect the future of valuable species. in the mixture. All this is, of course, much easier to say than to do. However, a few points other than the 
spelling and grazing times suggested are:- (a) in the establishment of a new pasture great care must be taken to adjust seeds mixture, fertilisers, sowing times, and early grazings to protect the young clovers in mixtures, especially with the very rapid early growing short-rotation and Italian ryegrasses, (b) in break , grazing of short-rotation rye pastures care must be 1 taken to move up the rear fences to protect the recovery growth of this ryegrass, its very rapid growing, erect, and relatively few tillers making it more suscep tible to damage and loss by this than other competing species in the mixture, (c) paddocks should not be continually used for seasonal spelling from grazing for different purposes, as, if so, the pasture balance will change to dominance by different species and probably suppress other desired species, especially the clovers.

\section{Animal Requirements}

From all our investigations to date on animal feed requirements and of associated digestion troubles such as feed flavours, bloat, and facial eczema, the evidence is strong that the really high-producing pasture of short-rotation ryegrass and white and red clovers offers the most trouble-free and easiest handled of the high production combinations, as well as providing the most satisfactory total and seasonal curve of feed supply. From the same work it appears that most of the feed supply and digestive troubles occur on the range of pastures in between the very low producers and the

-.. top-producing pasture mentioned. Of interest in this respect is our recent field work on bloat control carried out over the last two seasons in the Manawatu (5). In this we are getting good control by very intensive feed-by-feed rationing with the electric fence, but the only satisfactory pasture mixture for bloat control as well as for continued high, milk production is a relatively tall pasture of short-rotation rye and the clovers; the difficulty with perennial ryegrass is its rapid deterioration in palatibility and increase in toughness with increase in height, and the difficulty with other species is their low productivity at that time of the year.

With these facts in view, as well as for its other excellencies, we at Grasslands are rapidly fixing on the simple mixture of short-rotation ryegrass and white and, red clovers as being the most appropriate cornbination for high-production grassland farming, and with perennial ryegrass, cocksfoot, timothy, and/or 
subterranean clover used in special paddocks or ineluded in the general mixture for particular needs in cases of climatic, grazing, or soil-fertility weaknesses.

\section{General Farm Management}

To fit these several factors in a total workable and high-production farm scheme and especially to study the possibilities of adequately spread feed supplies other than by complete emphasis on such practices as silage, hay, and/or root and other forage crops, all with their own special brands of extra work and feed losses, I have for some years been running self-contained farmlet trials of different grassland systems at Palmerston North, Lincoln, and Gore. There can never, of course, be any clear-cut and indubitable findings from such trials, but several important clues have emerged from such farm system analyses. They have been at least sufficient to give several practical and presumably hard-headed farmers a sufficiently clear picture for them to have already made several satisfactory adjustments on their own farms. 'The main features to date of the Palmerston North trial, which is oriented toward normal dairy production needs, are:

1. The highest annual production has been from the farmlet where stock is continually adjusted

to pasture growth. Here we have averaged for the past four years an annual per acre consumption by the animals of over $9000 \mathrm{lb}$.

S.E., with average C.P. of over 20 per cent. This, on normal feed conversion standards, would be sufficient to feed fully 2 cows per acre each of $1000 \mathrm{lb}$. weight and producing $400 \mathrm{lb}$. of butterfat in 300 days. Our actual production, even with relatively inefficient wethers, has been over 1701b. of wool plus over 5001b. of other weight increase per acre each year. But there is on this farmlet too great a disparity between winter and spring growths, even with the best pasture we are able so to produce, with a ration of 1:4 when we need a ratio of some $1: 2$ or less.

2. On the farmlet where we level out the feed supply with hay/silage the total production has been about 10 per cent. lower than the first block. The general curve of feed supply has been better, however, especially in the early spring periods with the use of the conserved 
feed. On the other hand in most seasons there has been a relatively poor growth position in the summer owing to the effects of the cutting and the extra grazing pressure on the other paddocks at that time. Also there has been a greater amount of weed growth (docks) on this farmlet as well as the other results of poaching.

3. On the farmlet where we have separate blocks of different pasture mixtures, and each block is given differential spelling and grazing, to give a total sequence of'in situ feed to fit our required feed curve, the total 'production has been slightly better than the hay/silage block, but we have a little extra feed trouble in the early spring due to wet soil conditions and the low dry matter percentage of saved short-rotation ryegrass at that time. Another defect is that at Palmerston North we lose the red clover in the mixture after 2 or 3 years, from disease, possibly encouraged in the winterspelled pastures, and also by competition from the vigorous white clover.

4. On another unit we ran for 3 years a combination of winter and summer crops in rotation with our best general-purpose mixture. Results from this were that we were steadily getting further down the scale in total production, and over-all production was only 80 per cent of the control pasture block. Because of this, and with the red clover losses in mind, I changed over to a combination of summer crop (kales) and special-purpose mixtures on a lo-year cycle. In the 2 years under this there has been a steady lift, until now this is the best practical system of these four. Some advantage would be obtained from a little hay for early spring feed balance. With this system of summer crop and immediate sowing to pasture we have every summer a feed supply from the crop, a strong first-year red clover, and a lower second-year red clover supply, which, however, could usefully be used for hay. After this second crop of red we then forget this species and place the emphasis on the pasture's content of ryegrass and white clover and the small "proportion of timothy and/or cocksfoot. 73 
Although many farmers and others appear to have obtained useful tips from these farm management analyses, I have justifiably been criticised for using sheep in such work. I emphasise, however, that such trials are merely exploratory pilot efforts from which we can extend any useful ideas. This year $\mathrm{Mr}$ Johnson of Massey College and I have started a larger pilot trial on a 17-acre area of Massey Dairy Farm, using a group of cows and young stock and running the area as a self-contained unit. The general management to be followed is that of a lo-year rotation with summer crops into special-purpose pastures, with some hay/silage and an intensive grazing control with the electric fence. Each year one-tenth of the area will be ploughed ; feeding out having been carried out the previous winter on this area, fertility is thus raised to the maximum for a good crop.

Thus you can see that we are giving it a go to try and fit our plants, soil, climate, and animals into combinations that will not only achieve our present potential, but will do it with interesting and not too laborious calls on our physical efforts.

\section{REFERENCES}

(1) Corkill L. (1949) Proceedings N.Z. Grassland Association.

(2) Sears, P.D., and Newbold, R.P. (1942) N.Z. Journal Science and Tech, 24 364-611.

(3) Sears, P.D. (1949) Proceedings N.Z. Sheepbreeders Conference, Massey Agricultural College.

(4) Melville, J. (1949) Proceedings N.Z. Grassland Association.

(5) Tyrer, T. G. (1950) N.Z. Dairy Exporter, December, 1950.

\section{DISCUSSION}

Q. Do you consider lucerne has a place in your farmlet analyses?

A. Yes; we are using lucerne with cocksfoot as a summer feed provider at Lincoln, but at Palmerston North we feel that we can do better with other mixtures and get a better seasonal spread of production, with several peaks of growth rather than the single summer peak of lucerne.

Q. Does Mr Sears think that Zcwt. per acre of superphosphate will adequately maintain high production ? On my farm at Otaki I used up to 10cwt. superphosphate per acre, then cut down to 2cwt. per acre, but am finding it necessary and payable to go back to $7 \mathrm{cwt}$. per acre. 
A. Each farm is a separate problem depending on original soil fertility and that induced by the farming system in use. I advise the constant questioning of fertiliser practices by each farmer on his own farm, by such means as soil tests and also by leaving strips untopdressed and also by giving others much larger quantities than normal for comparison.

Q. I question the policy being advocated of reducing silage. Normally spring feed gets ahead so that farmers are forced to silage and hay. H1 ryegrass will only intensify the need for making more hay and silage. It is possible to buy in extra stock to control the extra spring feed, but silage returns more per $£ 1$ than when feed is fed to extra bullocks brought in.

A. The whole question hinges round the variation in normal district seasonal spreads of growth. Obviously there will be a greater overall need for conserved food in Southland than in the warmer northern districts. We will probably never get away from some silage-especially if we want to overcome growth differences year to year. However, if we can produce more out of season growth either by better species, fertilisers or irrigation or drainage etc., we can obviously get away with less conserved feed. For this purpose the short rotation ryegrass pastures mentioned are good, not only from the greater winter growth, but also from their greater palatability up to quite tall stages cf growth which lets us more or less "freewheel" from season to season.

Q. Which strain of red clover was used in the trials?

A. Actually Montgomery red was used in these trials, but we are getting best results from the new Certified cowgrass.

Q. Is short rotation ryegrass suitable for sheep grazing in the Poverty Bay area?

A. Short rotation ryegrass will not stand hard continuous grazing, but it is worth inclusion in your mixture, even for the shorter time it will last. You will have to watch your seed production side of the business in your district.

$\mathrm{Mr}$ 'Levy mentioned that $\mathrm{Mr}$ Corkill is proceeding with a long-rotation ryegrass, which it is hoped will do for the sheep man what the short-rotation rye is doing for the dairy, farm in the North Island. However perennial ryegrass is still the best standby and should not be dropped without very careful prior consideration of the performance and limitations of other species and strains.

Q. I have found red clover worse for bloat than white clover. What is Mr Sears' experience?

A. We also have had a lot of trouble from red clover, mainly in the autumn and where grazing at a short stage of growth. The only satisfactory system of bloat control I have been able to work out-and it is not perfect by a long way-is to break graze intensively, with many shifts each day, so that the cows eat all the herbage including the stems and more fibrous tissue at the base of the plants. . This overcomes the selection by the cows of the leafy parts, especially the clover. The best pasture for this is a fairly long pasture of short rotation ryegrass and the clovers,

Mr Hamblyn agreed with Mr Sears's method and said that it was a matter of giving several breaks each of $2 \mathrm{ft}$. to $3 \mathrm{ft}$. 
rather than one break of $10 \mathrm{ft}$. to $15 \mathrm{ft}$. It is particularly important to watch the first grazing after milking, but he thought that cutting and wilting of the-herbage was-much safer and better, taken over all pasture types.

Q. Mr Sears has deprecated silage, but if he does not make silage how does he control pastures in September and October?

A. It is easy to theorise on the value and need for silage making, 'but the farmers themselves are fully aware of the hard work involved at both ends of the job and are themselves giving their answer by their keenness to try and provide the feed for winter and summer by other means. Obviously such things as irrigation and drainage are high priorities, and in addition all I am trying to emphasise is the need for a better use of species that will grow in the off seasons and thus help to fill in the troughs of production so that more stock can be carried, which in turn will make better use of the feed which is at present an embarrassing surplus.

Q. Referring to your bloat control method, my feeling is that you may be forcing the animals to eat something they do not like and thus you will lower per cow production.

A. My attitude is that when you have bloat worries tho first care and major effort must be to control the bloat, simply to keep the herd alive; but actually our experience has been that. we have been able to control bloat by intensive break grazing control, and also keep the milk production high, on pastures which under open grazing have been very dangerous indeed. The system certainly calls for extra work, but no one grudges this if it means saving the cows. I would like $\mathrm{Mr}$ Johnson, of Massey College, to give a summary of our experiences with his herd of some 140 cows at Massey on' very bloaty pastures.

Mr Johnson said that he had had very good results over the, past 2 years and was quite confident that bloat could be kept under control and also per cow production kept up. At Massev the production this year drnnned considerably for 4 or 5 days after the first appearance of bloat under open grazing. Intensive grazing control with many shifts per day were then started on a sward with much perennial ryegrass and cocksfoot but the cows'sulked. A shift was then made to a naddock with much short rotation ryegrass and production started to go up and bloat was held in control: but the rise was not enough and so a more or less continuous fence shifting programme was started, and this was followed by a greater rise in production. However, this was a tough job, and it was also obvious that the cows were still not getting enough because of the large amount of tough perennial ryegrass in the sward, which probably meant too much effort for the cows in the actual eating process. Accordingly the mower was started and each day's feeds were cut and side-raked into rolls of feed, which could then be fed by less'frequent shifting of the fence. This helped considerably on this fairly tough pasture. However, in another group, on tall, short-rotation ryegrass and clover pasture, it was not necessary to use this mowing system. He did not agree with $\mathrm{Mr}$ Hamblyn that cutting and wilting was the answer unless the cut feed was rationed to the stock. Palatable grass species at a fair height were the keynote, and at Massey it was found that- the short-rotation ryegrass and the clovers were giving first-class material for the cows. 